\title{
The "Permission/Possibility/Ability" Modals in Malaysian English Textbooks: A Corpus-Based Analysis
}

\author{
Laleh Khojasteh,
} Shiraz University of Medical Sciences, Iran

Nasrin Shokrpour ${ }^{1}$

Shiraz University of Medical Sciences, Iran

\section{Introduction}

In Malaysia, one of the most fundamental language inputs received in the classroom by learners is a textbook (Nooreen, Arshad 2005). However, the prescribed Malaysian English language textbooks used in schools are often reported as being prepared through a process of material development involving intuition and assumption (Mukundan 2004; Mukundan, Roslim 2009; Mukundan, Khojasteh 2011). As a result of using intuition, one argument is that the existing textbooks lack a broad empirical basis. Ultimately, the manner through which materials are presented by the textbooks and learnt by the students is of prime importance.

In English, there are nine modal verbs that must certainly be included as the central modal auxiliary verbs, namely will, would, can, could, may, might, shall, should, and must (Hoye 1997). Although most grammarians and linguists have agreed upon nine central modals, Kurikulum Bersepadu Sekolah Menengah (KBSM) syllabus in Malaysia introduces only six central modals and one semi-modal for Malaysian secondary school textbooks. The modals shall, would and could are the modals that have not explicitly been taught in secondary school textbooks. It has been argued that the modal auxiliary system used in the Malaysian schools has been altered and functionally reduced through the continued use of fewer and semantically salient modals (De Silva 1981). The limited exposure of Malaysian learners to different

\footnotetext{
${ }^{1}$ Corresponding Author
} 
forms of modal verbs and their functions has resulted in an overuse of one form or function over the others (Wong 1983). The same observation has been made by Manaf (2007) who analyzed the modal auxiliary verbs in Malaysian learner corpus (EMAS). Although the lack of equal counterparts between the English modal system and that in Bahasa Melayu might be the reason for this confusion for Malay learners, Römer (2005) believes that this problem is owing to the teaching materials. The major aim of this textbook analysis, therefore, was to determine whether "permission", "possibility", and "ability" concepts of can, could, may and might which is presented in Malaysian English language textbooks are in line with those used by native speakers.

In this study, the leading question was: "How extensively "permission", "possibility", and "ability" meanings of four modal auxiliaries presented in Malaysian English language textbooks are in line with their usage in real language use.

\section{Semantic Functions of Modal Auxiliaries and ESL/EFL Learners}

The greatest difficulty for ESL/EFL learners lies in the meanings and uses of the modals (Celce-Murcia, Larsen-Freeman 1999). As the modals have more than one meaning or function, as well as "many nuances of meaning", even advanced ESL/EFL learners often have difficulty both in understanding the intended meanings and in choosing the correct modal auxiliary in the correct form to express what they actually mean (Decapua 2008). Cook (1978) indicated that learners encounter great difficulty in associating the right modal with the right meaning. This is compounded by the fact that the modals have social pragmatic functions related to politeness and status, which are not always easy for learners to distinguish and use (Collins 2009).

Can and could are among the very first modals that students are exposed to in their textbooks. However, they can also be very confusing for ESL/EFL learners at even higher levels of proficiency when students have to decide when and where they can replace could, for example, instead of can (Decapua 2008). Lack of distinguishing this can result in being rude and abrupt while making request (Decapua 2008).

Another source of difficulty for ESL/EFL students regarding modal auxiliaries is the fact that modals do not give grammatical information, and instead, they convey 
semantic and pragmatic information. On comparing "could you pass the salt, please?" with "pass the salt, please," it can be noted that the former sentence is more polite and less direct than the latter. This difference in the intention of speaker is indeed pragmatic information that can be conveyed by modal auxiliaries, suggesting possibility, granting permission, making deductions, judgments and assessments, indicating obligation, necessity and ability, advice, and expressing the speaker's attitude (Celce-Murcia and Larsen-Freeman 1999). According to Holmes (1988) while the native speakers use a variety of paralinguistic signals, such as eyebrow movement, facial expression, eye gaze, and gesture to convey their preferred modal meanings during face-to-face interaction, for non-native speakers, controlling this elusive aspect of meaning presents a great challenge.

Lock (1999) stated three ways in which modal verbs may be problematic to teach to ESL learners: 1) The same modal may be used to express quite different types of modal meanings,

2) Different modals may express very close or overlapping modal meanings, and

3) The precise meaning of the force of a modal may vary from context to context.

According to Celce-Murcia and Larsen-Freeman (1999), the difficulties faced by many ESL/EFL students are partly attributed to the fact that very few languages have modal auxiliaries in the extreme form as that in English; in other words, it is a separate verbal class that has very different syntactic properties from those of normal verbs. Bahiyah and Wijayasuriya (1998), in their discussion on modals in Bahasa Melayu, stated that the modals in both English and Bahasa Melayu do not bear a one-to-one relationship with each other, and that certain words that are modals in Bahasa Melayu are not modals in English and vice versa. Consequently, there is a tendency for ESL learners to directly translate the meanings of these modals from one language to the other, adding more confusion and impeding understanding to a certain extent.

\section{Methodology}

\section{Population and Sampling}

The pedagogic corpus that was used for this study consisted of five Malaysian secondary school English Language textbooks, comprising 280,000 running words. 
This textbook corpus has been used in many significant corpus-based studies (Mukundan, Menon 2006; Mukundan 2004; Mukundan, Roslim 2009; Mukundan, Khojasteh 2011), and the results have shed light on the lexical and grammatical structures that the secondary Malaysian students are exposed to in their classrooms.

\section{Instrumentation}

The WordSmith Tools 4.0 was used almost entirely for the purpose of this research, because it has been recognized as a capable and suitable tool to support quantitative and qualitative data analysis by many researchers (Baker 2006; Bondi 2001; De Klerk 2004; Flowerdew 2003; Henry, Roseberry 200; Menon 2009; Nelson 2001; Scott 2001).

\section{Data Analysis}

The data analysis procedure used in this study was based on the procedures carried out by various researchers (Holmes 1988; Meunier, Gouverneur 2009; Mindt 1991; Nordberg 2010; Römer 2004), studying the grammatical features in textbook corpus. As the focus of this study was on the meanings and communicative functions of four central modals, after coding the meanings of the modals, the corpus was analyzed quantitatively and qualitatively to determine the weight given to the assigned modal meanings in the textbook corpus. However, it is worth mentioning that the purpose of this qualitative content analysis was not to impose the pre-existing modal categories (such as "root" or "epistemic") on the modals analyzed in the corpus. The modal communicative functions were determined by examining the immediate context in which the modal was embedded. This study followed the possible meanings that each modal could convey based on the description of the modal semantic class (Biber, Johansson, Leech, Conrad, Finegan 1999). For example, the modal can has three possible meanings: "permission," "possibility," and "ability". Each of these semantic functions was analyzed quantitatively and qualitatively in each and every Form textbooks of 1-5. The summary of the results was then compared with the findings of the major corpusbased studies at the end of each section. 


\section{Results}

The "permission/ possibility/ ability" modals

First, we examined can and may along with their preterite counterparts could and might (including the negative forms can't, cannot, may not, couldn't, could not, might not). The highlighted cells in Table 1 are the modal auxiliary verbs stipulated by KBSM for Forms $1-5$ textbooks.

TABLE 1. Semantic distribution of the "ability/possibility/permission" modals in Forms 1-5 textbooks

\begin{tabular}{|c|c|c|c|c|c|c|c|c|}
\hline & Modal & Meaning & $\begin{array}{l}\text { Form } \\
1\end{array}$ & $\begin{array}{l}\text { Form } \\
2\end{array}$ & $\begin{array}{l}\text { Form } \\
3\end{array}$ & $\begin{array}{l}\text { Form } \\
4\end{array}$ & $\begin{array}{l}\text { Form } \\
5\end{array}$ & Total \\
\hline \multirow[t]{4}{*}{1} & Can & "ability" & 126 & 184 & 213 & 156 & 208 & 887 \\
\hline & & "possibility" & 71 & 33 & 29 & 77 & 59 & 269 \\
\hline & & "permission" & 20 & 6 & 8 & 2 & 6 & 42 \\
\hline & & Indeterminate & 26 & 33 & 21 & 6 & 5 & 90 \\
\hline \multirow[t]{4}{*}{2} & Could & "ability" & 24 & 11 & 30 & 29 & 36 & 130 \\
\hline & & "possibility" & 9 & 4 & 8 & 12 & 39 & 72 \\
\hline & & "permission" & 6 & - & 5 & - & 4 & 15 \\
\hline & & Indeterminate & 5 & 8 & 7 & 1 & 1 & 23 \\
\hline \multirow[t]{3}{*}{3} & May & "possibility" & 23 & 42 & 40 & 99 & 46 & 250 \\
\hline & & "permission" & 14 & 9 & 8 & 10 & 10 & 51 \\
\hline & & Indeterminate & - & 16 & 8 & 8 & 10 & 42 \\
\hline \multirow[t]{3}{*}{4} & Might & "possibility" & 4 & 8 & 16 & 8 & 18 & 54 \\
\hline & & "permission" & - & - & - & - & - & - \\
\hline & & Indeterminate & - & 10 & 7 & - & 10 & 27 \\
\hline
\end{tabular}

As can be seen in Table 1, none of the following modals has been assigned by KBSM for Form 1 textbook. With regard to can and could, the tendency for "ability" to be regarded as primary, "possibility" to be secondary, and "permission" to be tertiary could be observed. A considerable margin can be seen in terms of can, being dominantly dynamic with 126 instances (51.8\%), followed by the other two meanings of "possibility" (29\%) and "permission" (9.4\%). The same applies to could, although the numbers are less overwhelming. Could is the chief exponent for "ability" (24 instances), but it is less common in "possibility" and "permission" meanings ( 9 and 6 instances, respectively). Sentences 1 and 2 are samples for "ability" sense of could from textbook corpus.

Examples: (1) Sufian could not catch any fish because the river was polluted. 
(2) Sarimah said she could see to the bone. Mailin Lee Mei Mailin Oh dear!

It is clear from Table 1 that with regard to may, the "possibility" meaning (23 instances) was emphasized over the (deontic) "permission" meaning, while in the case of might, all the four frequency occurrences have been exclusively used to express "possibility" without one single instance to express "permission." (3), (4) and (5) are sample sentences for "possibility" and "permission" meaning of may and "possibility" meaning of might from textbook corpus.

Examples: (3) Message People may not be what they appear to be.

(4) Some words or phrases may be used more than once.

(5) You might lose it.

Comparison of the "possibility" meaning of all the four modal auxiliary verbs of can, could, may, and might shows that the "possibility" sense of can (66\%) is the most popular one used in the Form 1 textbook, which outstrips may (21\%), could (8.4\%), and might $(3.7 \%)$. A similar trend can be seen with regard to the "permission" meaning of the aforementioned modals. From Table 1, it can be noted that the "permission" meaning of can with frequency occurrence of 20 is dominant over may (14), with "permission", could and might being at best minor meanings (with only 9 and 0 instances, respectively). In addition, a considerable number of indeterminate cases, especially with regard to can and few cases for could, can also be observed.

For Form 2 textbook, "ability" and "possibility" can are assigned by KBSM for lower secondary school students. In addition, may and might are stipulated to express the "possibility" meanings. Furthermore, may is the only modal auxiliary verb, among this category, which is explicitly taught to either "ask for" or "give permission." In Form 2 textbook, while students are exclusively exposed to the "ability" meaning of can with frequency occurrence of 184 (71\%), only 33 instances $(12.8 \%)$ were tagged as "possibility" meaning and 6 instances $(2.3 \%)$ for "permission." (6), (7) and (8) are sample sentences for "ability" "possibility," and "permission" senses of can in Form 2 textbook.

Examples: (6) I can escape if I need to.

(7) Old jars and bottles can be reused for other purposes. 
(8) You can now use them to make patterns or pictures on cards.

A lesser marginal difference can be seen in terms of could and its related functions. Could has been found to be more frequently used in its "ability" sense (47.8\%) than "possibility" (4.7\%) sense. However, there is a paucity for "permission" meaning of could with absolutely 0 instances.

In terms of "possibility" sense in all the four modals, the frequency of may $(48 \%)$ in Form 2 textbook is observed to be greater than that of can (37\%), and that of might (9\%) outstrips (outnumber)??? could (4.5\%). Furthermore, while the "permission" (deontic) meaning of might and could is absolutely 0 , this meaning is found to occur with a slight majority of may (9 instances) than can (6 instances). The following example (9) is a sample sentence for "permission" meaning of may in Form 2 textbook.

Example: (9) May I borrow your English book, please?

For Form 3, KBSM stipulated similar modals and meanings assigned for Form 2 textbook. In this Form, can was assigned to express the "ability" meaning, while may and might were stipulated to express the "possibility" meaning.

As shown in Table 1, by far, the most frequent meaning in Form 3 is the "ability" sense of can with 213 instances (78\%), while there are only 29 instances (10\%) for its "possibility" meaning and 8 instances (3\%) for its "permission" sense. Similarly, could is dominantly dynamic (60\%), and (epistemic) "possibility" (16\%) and (deontic) "permission" senses (10\%) are the minor meanings. In the majority of cases (40 out of 56, i.e. 71\%), may indicates "possibility" rather than "permission." meaning. In addition, might is entirely epistemic with frequency occurrence of 16 for "possibility" meaning. (10) and (11) are sample sentences of "possibility" sense of might in Form 3 textbook.

Example: (10) You might fall and hurt yourself.

(11) Make predictions as to what might happen next in the story.

On comparing the "possibility" meaning of all the modals, we can observe that this sense has been dominantly presented by may (40 instances), followed by can (29), might (16), and could (8). However, 9 out of the 22 frequency occurrences of "permission" have been found to be expressed by can, followed by may and could, with 8 and 5 instances, respectively. 
Similar to Form 1, none of the "ability/possibility/permission" meanings have been stipulated for Form 4 textbook, and similar to that of Form 1, the share for the "ability" sense of can is found to still dominate the other meanings. Altogether, there have been 241 occurrences of can in the data, of which $156(64.7 \%)$ have been tagged as (dynamic) "ability," $77(31.9 \%)$ as "possibility," and only $2(0.8 \%)$ as "permission." Similarly, the "ability" meaning of could has been found to be more frequent than its "possibility" sense with 29 and 12 hits, respectively. Of all the 42 frequency occurrences for could, no instance of (deontic) "permission" meaning has been observed.

If we look at the distribution of the "possibility" meaning of all the four modals, we can observe that the most frequent modal is may with 99 hits, followed by 77 instances for can, 12 instances for could, and 8 instances for might. In addition, the Figure shows the predominance of the "permission" meaning of may (10 instances) and the scarcity of this meaning in terms of can, with only 2 frequency occurrences, and absolutely no instances in terms of could and might.

Similar to Forms 2 and 3 textbooks, the "possibility" senses of modals may and might have been stipulated by KBSM for the third time for Form 5 textbook. Table 1 shows that the "ability" meaning of can is constantly the most frequent meaning (181 hits). Similarly, the "possibility" can has the greater frequency occurrence (79), when compared with could with 36 instances, may with 46 instances, and might with 18 instances. It can be observed that could is more frequently expressed in the "possibility" sense (in $48 \%$ of the cases) than the "ability" sense with 36 cases. In contrast, the "permission" sense of all the modals is found to be very infrequent, when compared with their other meanings. The modals could, may, and might have been mainly used to convey the meaning of "possibility" rather than "permission" meaning, which has been observed to be fairly infrequent throughout the textbook.

\section{Discussion}

The previous sections dealt with the presentation of the semantic functions of can, could, may and might in Malaysian English language textbooks. The analysis highlighted the modals and their related semantic functions stipulated specifically for certain Forms (1-5). Now, this investigation will take one important step further to compare the textbook corpus findings with those of major corpus-based 
analyses on modal auxiliary verbs, and discuss the similarities and differences in the behavior of semantic functions of modals in English depicted in Forms 1-5 textbooks and real English language use. This section will discuss whether the language in the Malaysian English language textbooks mirrors the significant distribution of modal auxiliary verbs found in real English language use.

The results of the semantic analysis on the "permission/possibility/ability" modals present an interesting picture of the way these modals are portrayed in Malaysian English language textbooks of Forms 1-5. With regard to can, there is a massive bias towards (dynamic) "ability" meanings. Out of 1289 modal can within Forms $1-5$ textbooks, $68.8 \%$ are expressed in "ability" sense. This number is three times as frequent as the "possibility" meanings for can (20.8\%). These findings show that there are noticeable discrepancies when compared with the major studies on modal auxiliary verbs. For example, Biber, Johansson, Leech, Conrad and Finegan, (1999) listed "ability" and "possibility" meanings of can as equally frequent both in spoken and written registers. This is in line with the findings of Kennedy (2002) regarding the fact that both "possibility" and "ability" meanings of can are highly frequent in BNC, and there has been no mention regarding the tendency for can to primarily mark "ability" instead of "possibility." Showing the same bias, although less daunting, the results for could illustrate the predominance of the "ability" meaning (54\%) and the scarcity of the "possibility" meaning (30\%) throughout the textbooks of Forms 1-4, with the exception of Form 5 textbook, which in fact, in terms of could and its "ability/possibility" meanings, is the only Form that is in line with the results of the current studies. Biber, Johansson, Leech, Conrad and Finegan (1999) noted that could is much more common in expressing logical "possibility" rather than "permission" and "ability." This tendency has been confirmed by Collins (2009) in the British component of the International Corpus of English (ICE-GB), by Kennedy (2002) in the similarities found in spoken and written British English Corpus, and by Römer (2004) in his analysis on spoken British English corpus.

With regard to may and might, the general trend in the textbooks of Forms $1-5$ is clear: (epistemic) "possibility" meaning is emphasized in both the cases, while the (deontic) "permission" meaning is downplayed considerably. Although it seems that "possibility" may has been overused throughout the textbooks, this finding is in agreement with the current corpus-based studies. For instance, Leech, Hundt, Mair and Smith (2009) noted that while epistemic may has increased in frequency in recent decades, there has been a marked decline in the frequency of deontic may 
(mainly in speech). Leech (2004) also claimed that may is the chief exponent of epistemic "possibility" in British English. The same tendency towards monosemy of epistemic "possibility" may in British English has been reported by Leech (2004). Similarly, Biber, Johansson, Leech, Conrad and Finegan (1999) reported that may is used exclusively to mark logical "possibility" rather than "permission" in academic prose and conversation. In addition, might is dominantly epistemic "possibility," and the minor meaning of deontic "permission" is extremely rare according to Biber, Johansson, Leech, Conrad and Finegan (1999) and Römer (2004). Probably, that is the reason for might being solely used to express a "possibility" in the textbooks of Forms 1-5, and "permission" might did not occur even once throughout the textbooks. However, the portrayal of might from a frequency distribution point of view is not accurate in the Malaysian English language textbooks. Although might has been listed among the middle-to-low frequency modals, its "possibility" meaning outstrips the same meaning of may (Leech, Hundt, Mair, Smith 2009; Leech, 2004; Biber, Johansson, Leech, Conrad, Finegan 1999; Römer 2004). According to Leech, Hundt, Mair and Smith (2009), the "possibility" might is twice as frequent as may in spoken register. Accordingly, the bias towards the preference of "possibility" may over might can be seen in their frequency occurrences of "possibility" may with 250 instances, as opposed to "possibility" might with only 54 instances throughout the textbooks of Forms 1-5.

Traditionally, of the three modals dominantly used in asking for "permission", namely may, could, and can, the most formal and correct form was may (Biber, Johansson, Leech, Conrad and Finegan 1999). However, can has increasingly become the preferred form over may in terms of asking for "permission" (Decapua 2008) in real English language use. Similarly, Leech, Hundt, Mair and Smith (2009) noted a significant drop in the frequency of "permission" meaning of may over can, although this trend was more gradual in British English, as opposed to American English. Römer (2004) reported deontic "permission" meaning of can (23.5\%) favored over may (13\%), followed by could (3.5\%) and might $(3.5 \%)$ in BNC. This was also corroborated by the findings of Biber, Johansson, Leech, Conrad and Finegan (1999) who indicated that "permission" meaning of may has undergone a decline in frequency in recent decades. However, the findings of the present study suggest otherwise: not only are there relatively low tokens of "permission" meaning of can throughout the textbooks, but as Table 1 indicates, deontic "permission" may is constantly dominating can, except in Form 1 textbook. 


\section{Conclusion}

The main purpose of the present study was to examine the extent to which the semantic function of four modal auxiliary verbs is portrayed accurately in five Malaysian English Language textbooks (Forms 1-5). This study has demonstrated that these textbooks seem to offer a relatively one-sided picture, overemphasizing minor semantic functions at the expense of quite frequent functions in present-day English. In the case of modals of can, could, may, might, the treatment was heavily biased towards one of the meanings that the modals could have. The findings of this study reveal that although there are many invaluable insights available in terms of modal auxiliary verb forms and their semantic functions in major corpus-based studies carried out by Römer (2004), Kennedy (2002), Decapua (2008), Collins (2009) and many more, this real-life language has not been well represented in the Malaysian English language textbooks. This is rather surprising because with all the available information on modal auxiliaries and the existence of sophisticated software packages, it is not really clear what hinders the Malaysian authors from providing better quality information in Malaysian textbooks.

This discrepancy found in the Malaysian English language textbooks in terms of "permission/ possibility/ ability" meanings is in line with the findings of corpusbased analysis of Römer, (2004) and Nordberg (2010) on German and Finish Textbooks, respectively. Furthermore, this postulation is supported by some researchers such as Hyland (1994), Holmes (1988) and McEnery and Kifle (2002) who reported that textbooks that are not based on empirical studies misinform learners in terms of the range of modal language available to them, and provide inaccurate descriptions of both the qualitative functions of modality and the frequencies with which the modals occur.

\section{Suggestions for the Improvement of Teaching Materials}

Assuming that the aim of language instruction in Malaysian context is to move learners towards a standardized form of language usage and communicative competence, a couple of changes concerning the use of modal auxiliary verbs are suggested. First, if we intend to enable pupils to communicate successfully, it is important not to leave out some of the modal forms without explicit teaching. Based on Mindt's (1995) communicative grammar sense, textbook authors should focus their prime attention on the distribution of forms, functions, and contexts of 
modal auxiliary verbs in real language use. If this is the case, then, for example, could should be taught explicitly, because it is ranked among the four most frequent modals used by native speakers Quirk, Greenbaum, Leech, Svartvik 1985; Biber, Johansson, Leech, Conrad, Finegan 1999; Römer 2004; Kennedy 2002). Second, it is recommended that students should be exposed to the full array of meanings that modals can have. For example, being exposed to "permission" sense of can only with 6, 8, 2, and 6 instances in Form 2, 3, 4, and 5, respectively, cannot really guarantee learning this very important meaning in the present English. It has been estimated that when reading, words stand a good chance of being remembered if they have been met at least seven times over spaced intervals (Thornbury 2002). Therefore, our general recommendation would be to recycle various aspects of the target structures over a period of time.

\section{References and notes:}

Bahiyah A. \& Wijayasuriya, B. (1998). English Grammar for Malaysians. Bangi: Penerbit Universiti Kebangasaan Malaysia.

Baker, P. (2006). Using Corpora in Discourse Analysis. London: Continuum.

Biber, D., Johansson, S., Leech, G., Conrad, S. \& Finegan, E. (1999). Longman Grammar of Spoken and Written English. Harlow: Pearson Education.

Bondi, M. (2001). Small corpora and language variation: Reflexivity across genres. In M. Ghadessy, A. Henry, \& R. Roseberry (Eds.), Small corpus studies and ELT (pp. 135174). Amsterdam/ Philadelphia: John Benjamons Co.

Celce-Murcia, M. \& Larsen-Freeman, D. (1999). The Grammar Book: An ESL/EFL Teacher's Course. $2^{\text {nd }}$ ed. Boston: Thomson Heinle.

Collins, P. (2009). Modals and Quasi-Modals in English. Amsterdam: Rodopi.

Cook, W. (1978). Semantic structure of English modals. TESOL Quarterly, Vol. 12, 5-16.

Decapua, A. (2008). Grammar for Teachers. New Rochelle: Springer.

De Klerk, V. (2004). The use of 'actually' in spoken Xhosa English: A corpus study. World Englishes, Vol. 24(3), 275-288.

De Silva, E. (1981). Forms and functions in Malaysian English: the case of modals. SARE, Vol. 3, 11-23.

Flowerdew, L. (2003). A combined corpus and systematic-functional analysis of the problem solution pattern in a student and professional corpus of technical writing. TESOL Quarterly, Vol. 37(3), 489-511.

Henry, A. \& Roseberry, R. L. (2001). Using a small corpus to obtain data for teaching a genre. In M. Ghadessy, A. Henry, \& R. Roseberry (Eds.), Small corpus studies and ELT (pp. 93-113). Amsterdam/ Philadelphia: John Benjamons Co.

Holmes, J. (1988). Doubt and certainty in ESL textbooks. Applied Linguistics, Vol. 9(1), 21-44.

Hoye, L. (1997). Adverbs and Modality in English. London: Longman.

Hyland, K. (1994). Hedging in academic writing and EAP textbooks. English for Specific Purposes, Vol. 13(3), 239-56.

Kennedy, G. (2002). Variation in the distribution of modal verbs in the British National Corpus. In R. Reppen, S. Fitzmaurice, \& D. Biber (Eds.), Using corpora to 
explore linguistic variation (pp. 74-90). Amsterdam/ Philadelphia: John Benjamins Publishing Co.

Leech, G. (2004). Meaning and the English Verb ( ${ }^{\text {rd }}$ edition). London: Pearson Educational Limited.

Leech, G., Hundt, M., Mair, C. \& Smith, N. (2009). Change in Contemporary English. New York: Cambridge University Press.

Lock, G. (1999). Functional English Grammar. In J.C. Richards (Ed.). An introduction for second language teachers. Cambridge: Cambridge University.

Manaf, U. K. (2007). The Use of Modals in Malaysian ESL Learners' Writing. Unpublished Doctoral Thesis. Serdang: Universiti Putra Malaysia.

McEnery, T. \& Kifle, N.A. (2002). Epistemic modality in argumentative essays of secondlanguage writers. In J. Flowerdew (Ed.) Academic discourse (pp. 182-215). London: Longman.

Menon, S. (2009). Corpus-Based Analysis of Lexical Patterns in Malaysian Secondary School Science and English for Science and Technology Textbooks. Unpublished Doctoral Thesis. Serdang: Universiti Putra Malaysia.

Meunier, F. \& Gouverneur, C. (2009). New types of corpora for new educational challenges: collecting, annotating and exploiting a corpus of textbook material. In Aijmer, K. (Ed.) Corpora and language teaching. Benjamins.

Mindt, D. 1991. Syntactic evidence for semantic distinctions in English. In K. Aijmer \& B. Altenberg (Eds.). English corpus linguistics: Studies in honour of Jan Svartvik (pp. 183-196). London/New York: Longman.

Mindt, D. (1995). An Empirical Grammar of the English Verb: Modal Verbs. Berlin: Cornelsen Press.

Mukundan, J. (2004). A Composite Framework for ESL Textbook Evaluation. Unpublished Doctoral Thesis. Serdang: Universiti Putra Malaysia.

Mukundan, J. \& Menon, S. (2006). The Language of Form One Mathematics, Science and English Language Textbooks. A Comparative Corpus-based Study.Unpublished project work (PRPi). Serdang: Universiti Putra Malaysia.

Mukundan, J. \& Roslim, N. (2009). Textbook Representation of Prepositions. English Language Teaching, Vol. 2(4), 123-130.

Mukundan, J. \& Khojasteh, L. (2011). Modal Auxiliary Verbs in Prescribed Malaysian English Textbooks. English Language Teaching, Vol. 4(1), 79-89.

Nelson, M. (2001). A Corpus based Study of Business English and Business Teaching. Oxford: Oxford University.

Nooreen, N \& Arshad Abd. S. (2005). Examining the Importance of EST and ESL Textbooks and Materials: Objectives, Content and Form. English for Specific Purposes World. Retrieved December 19, 2009 from http://www.espworld.info/Articles_9/textbooks.htm .

Nordberg, T. (2010). Modality as Portrayed in Finish Upper Secondary School EFL Textbooks: A Corpus-based Approach. Master's Thesis. University of Helsinki. Retrieved August 20, 2010 from https://helda.helsinki.fi/handle/10138/19357

Quirk, R.S., Greenbaum, S., Leech, G., \& Svartvik, J. (1985). A Comprehensive Grammar of the English Language. Harlow: Longman.

Römer, U. (2004). A corpus-driven approach to modal auxiliaries and their didactics. In J. Sinclair (Ed.). How to use corpora in language teaching (pp. 185-199). Amsterdam: John Benjamins. 
Römer, U. (2005). Progressives, Patterns, Pedagogy. A Corpus-driven Approach to English Progressive Forms, Functions, Contexts and Didactics. Amsterdam: John Benjamins.

Scott, M. (2001). Comparing corpora and identifying key words, collocations and frequency distributions through WordSmith Tolls suite of computer programs. In M. Ghadessy, A. Henry, \& R.L. Roseberry (Eds.), Small corpus studies and ELT (pp. 47-67). Amsterdam/ Philadelphia: John Benjamins Publishing Co.

Thornbury, S. (2002). How to Teach Vocabulary. Malaysia: Pearson Education Limited. Wong, I. (1983). Simplification Features in the Structure of Colloquial Malaysian English. Singapore: Singapore University.

\title{
Summary
}

\section{The "Permission/Possibility/Ability" Modals in Malaysian English Textbooks: A Corpus-Based Analysis}

\author{
Laleh Khojasteh, \\ Shiraz University of Medical Sciences, Iran \\ Nasrin Shokrpour, \\ Shiraz University of Medical Sciences, Iran
}

\begin{abstract}
Malaysian learners are observed to be error-prone in terms of semantic functions of modal auxiliary verbs in English. ESL Malaysian learners' challenges in terms of using modal auxiliary verbs suggest that there might be some inadequacies in the syllabus, which could have led to the problems encountered by these students. Thus, the semantic functions of four modal auxiliary verbs, can, could, may and might, used by and introduced to Malaysian learners in Forms 1-5 textbook corpus were the focus of this study. Apparently, the findings show that these textbooks offer a relatively one-sided picture, overemphasizing the minor semantic functions and overlooking the frequent functions used in the presentday English. It is also argued that although there are invaluable insights available in terms of modal auxiliary verb forms and their semantic functions in major corpus-based studies, this real-life language has not been well presented in Malaysian English language textbooks. The findings of this study contribute to the improvement of the pedagogical practices in the teaching of the modal system, and emphasize that the semantic functions of each core modal in the teaching materials should be given adequate importance.
\end{abstract}

Keywords: Modal auxiliary verbs, prescribed textbooks, Corpus-based analysis, Pedagogic corpus 